\title{
Analisis Kandungan Zat Gizi, Pati Resisten, Indeks Glikemik, Beban Glikemik dan Daya Terima Cookies Tepung Pisang Kepok (Musa paradisiaca) Termodifikasi Enzimatis dan Tepung Kacang Hijau (Vigna radiate)
}

\author{
Analysis of Nutrients Content, Resistant Starch, Glycemic Index, Glycemic Load and Acceptability of \\ Modified Kepok Flour (Musa paradisiaca) and Mung Bean Flour (Vigna radiata) Cookies \\ Diana Nur Afifah*, Lili Nor Indah Sari, Dwi Ratna Sari, Enny Probosari, Hartanti Sandi Wijayanti, Gemala Anjani \\ Departemen IImu Gizi, Fakultas Kedokteran, Universitas Diponegoro, Semarang \\ *Korespondensi dengan penulis (d.nurafifah.dna@fk.undip.ac.id) \\ Artikel ini dikirim pada tanggal 14 Juni 2020 dan dinyatakan diterima tanggal 26 Juli 2020. Artikel ini juga dipublikasi secara online melalui \\ https://ejournal2.undip.ac.id/index.php/jatp. Hak cipta dilindungi undang-undang. Dilarang diperbanyak untuk tujuan komersial. \\ Diproduksi oleh Indonesian Food Technologists $®$ (C2020
}

\begin{abstract}
Abstrak
Upaya pengendalian diabetes mellitus tipe-2 dapat dikontrol melalui pola makan, salah satunya yaitu dengan modifikasi jenis makanan yang selain memenuhi kebutuhan gizi juga dapat mengendalikan kadar glukosa darah. Pisang kepok dan kacang hijau memiliki kandungan pati resisten, serat pangan, protein yang cukup tinggi, dan indeks glikemik rendah sehingga dapat digunakan sebagai alternatif bahan pembuatan cookies untuk penderita diabetes mellitus tipe-2. Penelitian ini bertujuan untuk menganalisis kandungan gizi, pati resisten, indeks glikemik, beban glikemik dan daya terima cookies tepung pisang kepok termodifikasi enzimatis dan tepung kacang hijau. Penelitian ini menggunakan rancangan acak lengkap satu faktor dengan perbandingan variasi pisang kepok termodifikasi dan tepung kacang hijau masing-masing dengan persentase sebesar 85:15; 75:25; dan 65:35. Kandungan gizi dianalisis dengan metode uji proksimat. Analisis indeks glikemik dan daya terimanya juga dilakukan pada penelitian ini. Formula terbaik dianalisis dengan metode de Garmo. Hasil penelitian menunjukkan bahwa formulasi terbaik didapat dari cookies dengan formulasi $85 \%$ tepung pisang kepok termodifikasi enzimatis dan $15 \%$ tepung kacang hijau dengan nilai hasil tertinggi sebesar 0,599 dengan kandungan karbohidrat $45,72 \%$, protein $5,62 \%$, lemak $18,53 \%$, air $11,22 \%$, abu $3,70 \%$, serat pangan $15,18 \%$, pati resisten $13,67 \%$, indeks glikemik 33,20 dan beban glikemik 4,19. Kesimpulan yang didapat dari penelitian ini adalah kandungan zat gizi cookies tepung pisang kepok termodifikasi enzimatis dan tepung kacang hijau dapat ditentukan dengan baik dengan menemukan formula terbaiknya, yaitu $85 \%: 15 \%$.
\end{abstract}

Kata kunci: tepung pisang kepok, tepung kacang hijau, beban glikemik, indeks glikemik, kandungan gizi.

\section{Abstract}

Type 2 diabetes mellitus can be controlled through diet, one of which is by modifying the type of food that helps fulfilling nutrient-needs and control blood's glucose levels. Kepok banana and mung bean contain high resistant starch, dietary fiber, protein, and low glycemic index so it can be used as an alternative ingredient in making cookies for people with type 2 diabetes mellitus. This study aimed to analyze the nutrients content, resistant strach, glycemic index, glycemic load and acceptability of cookies from enzymatically modified kepok banana flour and mung bean flour. The completely randomized one-factor experimental study with ratio of modified kepok banana : mung bean flour i.e. 85:15; 75:25; and 65:35. Nutrient content was analyzed by proximate methods. The glycemic index and glycemic load were also analyzed as well as acceptability test. The best formula was determined by the de Garmo method. As results, the quality of nutrient content, resistant starch, glycemic index, glycemic load and acceptance, were achieved with formula of $85 \%$ modified kepok flour and 15\% mung bean flour resulting high yield value of 0.599. the best cookies formula contained carbohydrate of $45.72 \%$, protein of $5.62 \%$, fat of $18.53 \%$, water of $11.22 \%$, ash of $3.70 \%$, fiber of $15.18 \%$, resistant starch of $13.67 \%$, glycemic index of 33.20 , and glycemic load of 4.19 . As conclusion, all treatment was successfully revealed and generated the best formula or $85 \%: 15 \%$ for the ratio of modified kapok flour and mung been flour.

Keywords: Kepok banana flour, mung bean flour, glycemic index, glycemic load, nutrient content.

\section{Pendahuluan}

Diabetes melitus (DM) adalah penyakit metabolik yang ditandai dengan tingginya kadar glukosa dalam darah seseorang, hal ini disebabkan karena kerusakan sekresi insulin, terganggunya kerja insulin, atau bahkan keduanya (Canivell and Gomis, 2014). Secara global, menurut Cho et al. (2018) prevalensi DM pada orang dewasa di tahun 2017 mencapai angka 451 juta orang dan diperkirakan pada tahun 2045 dapat meningkat menjadi 693 juta orang. Di Indonesia, prevalensi DM tipe 2 diperkirakan meningkat mencapai $154 \%$ pada tahun 2030 (Wild et al., 2004). Laporan hasil Riskesdas terbaru menunjukkan prevalensi DM berdasarkan pemeriksaan gula darah naik dari 6,9\% pada tahun 2013 menjadi 
8,5\% pada tahun 2018 (Kemenkes, 2018). Diantara tipetipe DM, DM tipe 2 merupakan tipe penyakit diabetes yang paling banyak diderita. DM tipe 2 bersifat progresif, sehingga dalam penatalaksanaannya diperlukan kontrol gula darah agar keadaan tidak memburuk dan mencegah terjadinya risiko komplikasi (Franz, 2012).

Pengendalian diabetes mellitus dapat dilakukan dengan melakukan kontrol pada faktor risiko yang dapat dimodifikasi, salah satunya yaitu pola makan yang seimbang. Strategi dalam pengaturan pola makan untuk membantu mengendalikan glukosa darah salah satunya yaitu dengan mengkonsumsi makanan yang tidak menimbulkan peningkatan glukosa darah secara cepat (Franz, 2012; Siagan, 2004). Jenis bahan makanan yang dianjurkan untuk penderita DM tipe 2 adalah makanan yang kaya serat dan karbohidrat kompleks, salah satu contoh bahan tersebut adalah pati resisten (Siagan, 2004). Konsumsi pangan tinggi serat, pati resisten, dan indeks glikemik (IG) rendah dapat menurunkan laju penyerapan glukosa, memperbaiki sensitivitas insulin, serta bermanfaat dalam pengendalian glukosa darah sehingga dapat menurunkan risiko komplikasi pada penderita DM tipe 2 (Zhang et al., 2007). Disamping mengkonsumsi makanan dengan indeks glikemik rendah, World Health Organization (WHO) juga merokemendasikan penderita DM untuk memperhatikan jumlah karbohidrat yang dikonsumsi, sehingga selain IG, beban glikemik (BG) juga perlu diperhatikan karena beban glikemik memperhitungkan jumlah kandungan karbohidrat yang ada dalam setiap porsi makan, tidak hanya melihat jenisnya seperti IG (Granfeldt et al., 2006).

Buah pisang merupakan bahan makanan yang mudah ditemukan di Indonesia, banyak dikonsumsi, dan memiliki kandungan pati cukup tinggi. Kandungan pati yang terdapat dalam buah pisang rata-rata lebih dari $20 \%$, sehingga buah pisang cukup potensial dikembangkan sebagai sumber pati resisten (Aquino, 2016). Selain itu pisang kapok mentah juga mengandung tinggi serat dan berindeks glikemik rendah (Diyah et al., 2016). Pisang kepok memiliki nilai indeks glikemik rendah, yaitu 43 dan mengandung serat pangan seperti pati resisten yang cukup tinggi, sebesar 27,7\% (Musita, 2012; Diyah et al., 2016). Kandungan pati resisten yang tinggi dalam suatu makanan diduga memiliki nilai indeks glikemik rendah, hal ini berkaitan dengan sifat dari pati resisten yang tidak dapat dicerna oleh enzim pada saluran pencernaan manusia, sehingga peningkatkan kadar glukosa dalam darah menjadi lebih lambat (Robertson, 2012). Faktor - faktor yang mempengaruhi proses pembentukan pati resisten adalah kandungan air pada pati, suhu pemanasan bertekanan, jumlah siklus autoclaving - cooling, rasio kandungan amilosa dan amilopektin. Kandungan pati resisten dalam bahan pangan dapat ditingkatkan dengan beberapa cara baik secara fisik, kimia, maupun enzimatis diantaranya melalui pemanasan bertekanan pendinginan (autoclaving- cooling) beberapa siklus, hidrolisis asam di bawah suhu gelatinisasi (proses lintnerisasi), dan pemutusan rantai cabang amilopektin (debranching) dengan enzim pullulanase yang dikombinasikan dengan autoclaving- cooling (Setiarto et al., 2015). Berdasarkan penelitian sebelumnya, diketahui bahwa modifikasi peningkatan kadar pati resisten pada tepung pisang dengan cara kombinasi autoclaving-cooling enzimatik dapat ditingkatkan menjadi 71,3\% (Nurhayati et al., 2014). Dengan dibuat menjadi tepung, pisang diharapkan dapat dioptimalkan penggunaannya melalui modifikasi nilai IG dengan mensubtitusi tepung terigu dengan tepung pisang kepok pada olahan tepung terigu (Afifah et al., 2018).

Pisang cenderung memiliki kadar protein yang rendah, sehingga untuk meningkatkan kadar protein dapat dilakukan dengan mengkombinasikan dengan bahan dari kacang-kacangan seperti kacang hijau. Kacang hijau tinggi akan protein, serat serta rendah lemak jenuh. Kacang hijau memiliki kandungan protein yang cukup tinggi yaitu 22,2 g, kandungan serat 4,1 g, kandungan pati resisten $2,33 \%$ serta kandungan lemak kacang hijau 1 - 1,2 \% (Purwono dan Hartono, 2005). Selain nilai kandungan protein dan serat yang cukup tinggi, kacang hijau juga memiliki nilai indeks glikemik yang rendah sebesar 28,87 (Atkinson et al., 2008). Kandungan protein pada pangan dapat mempengaruhi nilai IG dengan merangsang sekresi insulin, sehingga menghambat terjadinya peningkatan glukosa darah postprandial (Mustakim, 2013). Kadar serat yang tinggi akan berkontribusi pada nilai IG rendah dengan meningkatkan viskositas, memberikan rasa kenyang yang lebih lama dan menurunkan absorpsi makronutrien (glukosa) sehingga akan menurunkan glukosa darah postprandial dan insulin (Istiqomah, 2015).

Pola makan penderita DM dengan porsi kecil dan sering, sehingga selain makanan utama juga dibutuhkan modifikasi makanan selingan yang mampu memberikan kontribusi kecukupan gizi dengan tetap memperhatikan kandungan gizi, pati resisten, indeks glikemik dan beban glikemik sehingga membantu mengendalikan glukosa darah. Pembuatan cookies dengan bahan baku tepung pisang kepok termodifikasi dan tepung kacang hijau belum pernah dilakukan sebelumnya. Berdasarkan penelitian terdahulu, pembuatan krakers substitusi tepung pisang kepok kuning 50\% dengan kombinasi fermentasi spontan dan autoclaving-cooling menghasilkan krakers dengan IG rendah yaitu 38,42 (Afifah et al., 2018). Cookies merupakan salah satu produk yang banyak dikonsumsi oleh masyarakat dan juga tahan lama dalam penyimpanannya. Berdasarkan latar belakang diatas, maka penelitian ini bertujuan untuk menganalisis kandungan gizi, pati resisten indeks glikemik, beban glikemik dan daya terima pada formulasi cookies tepung pisang kepok termodifikasi dan tepung kacang hijau sebagai alternatif makanan selingan penderita DM tipe-2 yang selain mencukupi kebutuhan gizi juga dapat membantu mengendalikan glukosa darah.

\section{Materi dan Metode \\ Materi}

Bahan-bahan yang digunakan dalam pembuatan cookies penelitian ini adalah tepung pisang kepok yang telah diberi perlakuan modifikasi secara autoclaving 
cooling enzimatis autoclaving cooling, kacang hijau, enzim pullulanase, margarin, gula stevia, putih telur, baking powder dan pengemulsi. Alat yang digunakan meliputi cabinet dryer (Getra, Indonesia), blender merk Miyako, ayakan 80 mesh (B-ONE, RRC), autoclave (My life MA678, Indonesia) untuk tahap awal pembuatan tepung pisang kepok termodifikasi, baskom, cetakan cookies, dan oven (Memmert GmbH, Jerman) untuk proses pembuatan cookies. Sedangkan kuisioner digunakan untuk mengukur daya terima produk. Pengukuran glukosa darah menggunakan alat tes glukosa GCHb merk EasyTouch, lancet (Gea Medical, Taiwan), sampel whole blood (darah kapiler) sebanyak 1-2 ml, strip (EasyTouch, China), dan alcohol swap.

\section{Metode}

Penelitian ini merupakan penelitian eksperimental dengan Rancangan Acak Lengkap (RAL) satu faktor, yaitu variasi formula tepung pisang kepok termodifikasi dan tepung kacang hijau pada pembuatan cookies. Pada penelitian ini dilakukan 3 taraf perlakuan rasio pisang : kacang hijau sebesar $85: 15 \%, 75: 25 \%$, dan 65:35\% dengan 3 kali pengulangan dan setiap pengukuran dilakukan secara duplo. Pembuatan dan penentuan 3 formula cookies dilakukan pada tahap penelitian pendahuluan, selanjutnya pada tahap persiapan dilakukan pembuatan cookies kemudian pelaksanaan penelitian. dan daya terima.

Proses Pembuatan Tepung Pisang Kepok Termodifikasi Proses pembuatan cookies terlebih dahulu dilakukan dengan pembuatan tepung pisang kepok termodifikasi autoclaving-cooling enzimatis autoclavingcooling (Afifah et al., 2018). Proses pembuatan tepung pisang kepok termodifikasi dimulai dari pisang kepok kuning dicuci dan dikupas dari kulitnya, kemudian diiris tipis untuk dikeringkan menggunakan oven dengan pengaturan suhu $50{ }^{\circ} \mathrm{C}$ selama 24 jam. Pisang kepok yang telah kering dihaluskan dengan menggunakan blender dan dilakukan pengayakan. Kemudian dilakukan proses autoclaving pada suhu $121^{\circ} \mathrm{C}$ selama 15 menit dan cooling pada suhu $4{ }^{\circ} \mathrm{C}$ selama 24 jam. Tepung ditambahkan dengan enzim pullulanase sebanyak $2 \%$ dan diinkubasi dalam shaker incubator pada suhu $37^{\circ} \mathrm{C}$, $150 \mathrm{rpm}$ selama 15 jam. Reaksi dihentikan (inaktifikasi enzim) dengan memanaskan sampel pada suhu $85^{\circ} \mathrm{C}$ selama 5 menit. Selanjutnya dilakukan proses autoclaving dan cooling lagi.

Tabel 1. Formulasi bahan pembuatan cookies (dalam g) Jenis Bahan Persentase tepung pisang dan

\begin{tabular}{lccc} 
& \multicolumn{3}{c}{ kacang hijau } \\
\cline { 2 - 4 } & $85: 15$ & $75: 25$ & $65: 35$ \\
\hline Tepung pisang & 170 & 150 & 130 \\
Tepung kacang hijau & 30 & 50 & 70 \\
Margarin & 60 & 60 & 60 \\
Gula Stevia & 8 & 8 & 8 \\
Putih Telur & 50 & 50 & 50 \\
Baking Powder & 2 & 2 & 2 \\
Pengemulsi & 24 & 24 & 24 \\
\hline
\end{tabular}

Proses Pembuatan Cookies

Bahan baku pembuatan cookies adalah tepung pisang kepok termodifikasi enzimatis, tepung kacang hijau, margarin, putih telur, gula stevia, baking powder, dan pengemulsi. Cara pembuatan cookies adalah margarin dan pengemulsi dicampur ke dalam mangkuk dan diaduk hingga rata. Kemudian di tambahkan putih telur lalu diaduk kembali hingga rata. Selanjutnya ditambahkan gula rendah kalori ke dalam adonan dan diaduk lagi hingga merata. Campuran tepung kacang hijau, tepung pisang kepok termodifikasi, dan baking powder ditambahkan dengan adonan margarin lalu diaduk rata hingga membentuk adonan kue. Setelah itu adonan dicetak. Adonan yang sudah dicetak dipanggang dalam oven dengan suhu $120{ }^{\circ} \mathrm{C}$ selama 20 menit. Komposisi bahan yang digunakan pada tiap formulasi dapat dilihat pada Tabel 1 .

\section{Prosedur Analisa Proksimat}

Uji proksimat dilakukan sesuai dengan prosedur AOAC (2005) pada cookies yang meliputi analisis kandungan zat gizi yaitu protein dianalisis dengan metode Kjeldahl, lemak dengan metode Soxhlet, karbohidrat dengan metode by difference, kadar air dengan metode oven (Sudarmadji, 1997); kadar abu dengan metode pengabuan kering (Andarwulan, 2011); kadar serat pangan menggunakan metode enzimatik gravimetri (Asp, 1983); pati resisten dianalisis dengan metode Kim et al. (2003).

Prosedur Analisis Indeks Glikemik dan Beban Glikemik

Uji indeks glikemik menggunakan desain rancangan one-shot case study, yaitu memberikan perlakuan secara sengaja kepada subjek terhadap pangan acuan (roti tawar) dan cookies, kemudian mengukur glukosa darah setelah perlakuan tersebut (Brouns et al., 2019). Sebanyak 54 gram roti tawar yang mengandung 25 gram available carbohydrate dihitung jumlahnya berdasarkan informasi nilai gizi yang tertera pada label di kemasan, sementara jumlah cookies yang diberikan dihitung berdasarkan hasil uji proksimat pada masing-masing formula. Perhitungan beban glikemik (BG) menggunakan perhitungan Venn et al. (2006) dengan mengalikan IG dengan kadar available carbohydrate cookies tepung pisang kepok dan tepung kacang hijau per porsi kemudian dibagi 100.

\section{Prosedur Uji Daya Terima}

Uji daya terima meliputi tingkat kesukaan aroma, warna, tekstur dan rasa yang menggunakan 4 skala, yaitu 1 = sangat tidak suka, 2 =tidak suka, $3=$ suka dan $4=$ sangat suka. Uji tersebut dilakukan pada 25 panelis semi terlatih dari Program Studi Gizi Fakultas Kedokteran Universitas Diponegoro dengan pengujian sebanyak satu kali. Formulasi cookies terbaik dipilih berdasarkan indeks efektivitas yang menggunakan metode de Garmo et al. (1984).

Analisis Statistik

Data yang terkumpul dianalisis dengan menggunakan program SPSS 16 for Windows. 
Pengaruh formulasi cookies tepung pisang kepok termodifikasi terhadap kandungan zat gizi lemak, abu dan serat pangan diuji dengan One Way Anova dan dilanjutkan dengan Posthoc Test LSD untuk mengetahui beda nyata antar perlakuan. Sementara itu, untuk mengetahui pengaruh formulasi cookies tepung pisang kepok teermodifikasi dan tepung kacang hijau terhadap kandungan karbohidrat, lemak, air, pati resisten dan daya terima cookies digunakan uji Kruskal-Wallis Test yang dilanjutkan dengan uji Mann Whitney-U Test.

\section{Hasil dan Pembahasan}

\section{Kandungan Zat Gizi Cookies}

Hasil analisis kandungan zat gizi cookies pada Tabel 2 menunjukkan bahwa ada perbedaan nyata pada kandungan protein, lemak, karbohidrat, kadar abu, kadar air dan serat pangan pada cookies tepung pisang kepok termodifikasi enzimatis dan tepung kacang hijau di masing-masing formula. Kandungan protein cookies berada dalam kisaran 5,62-7,83 g/100 g, lemak di antara $18,45-18,99 \mathrm{~g} / 100 \mathrm{~g}$, karbohidrat 40,16-45,72 g/100 g, kadar air 9,83-12,22\%, kadar abu 3,65-4,45\%, dan serat pangan sebesar 15,18-17,70 g/100 g. Berdasarkan data yang didapat, semakin berkurangnya komposisi tepung pisang kepok termodifikasi dan semakin banyaknya komposisi tepung kacang hijau yang digunakan maka semakin meningkatkan kandungan protein dan serat pangan cookies. Substitusi tepung kacang hijau dapat meningkatkan kandungan protein cookies sebesar 0,82$1,40 \mathrm{~g}$ pada tiap formulasi.

Kadar protein cookies semua perlakuan telah memenuhi SNI 2973:2011, yaitu dengan kadar protein minimal $5 \%$. Konsumsi protein bernilai biologis tinggi yang dapat meningkatkan penyerapan dan penggunaan nitrogen, sehingga mengurangi sisa hasil metabolisme protein dalam tubuh dan tidak memperberat ginjal penderita DM tipe-2 (Gallagher, 2012). Kandungan karbohidrat pada cookies Nampak semakin menurun dengan berkurangnya komposisi tepung pisang kepok termodifikasi yang diberikan. Cookies dengan formulasi pisang $65 \%$ dan kacang hijau 35\% mempunyai kandungan karbohidrat terendah yaitu sebesar $40,16 \%$. Kandungan karbohidrat pada cookies tepung pisang kepok termodifikasi enzimatik dan tepung kacang hijau telah memenuhi syarat mutu dari SNI 01-2973-1992 tentang mutu biskuit, yaitu lebih rendah dari $70 \%$. Hasil analisis kadar lemak pada cookies tepung pisang kepok termodifikasi dan tepung kacang hijau berkisar 18,45$18,99 \mathrm{~g} / 100 \mathrm{~g}$ dan nampak adanya ketidakstabilan nilai. Peningkatan kandungan lemak terjadi karena kandungan lemak pada tepung kacang hijau $(1,26 \mathrm{~g} / 100$ g) lebih tinggi daripada tepung pisang kepok $(0,9-1 \mathrm{~g} / 100$ g). Selain itu, sumber lemak pada cookies berasal dari margarin dan pengemulsi. Ketidakstabilan nilai juga nampak pada kadar air dan kadar abu. Kandungan serat pangan cookies semakin meningkat dengan semakin besarnya presentase tepung kacang hijau. Menurut Olwin dan Cornelis (2005) peningkatan kandungan serat pangan ini dikarenakan kandungan serat pangan pada tepung kacang hijau $(4,3 \mathrm{~g} / 100 \mathrm{~g})$ yang lebih tinggi daripada tepung pisang kepok $(0,6 \mathrm{~g} / 100 \mathrm{~g})$. Serat dapat memperlambat pengosongan lambung, memperpendek waktu transit makanan di usus, dan memperlambat penyerapan glukosa sehingga dapat mengurangi peningkatan glukosa darah (Franz, 2012).

\section{Kandungan Pati Resisten Cookies}

Pati resisten dalam bahan makanan di bagi menjadi lima golongan antara lain; (a) sangat rendah $(<1 \%)$, (b) rendah (1-2,5\%), (c) sedang $(2,5-5 \%)$, (d) tinggi $(5-15 \%)$ dan (e) sangat tinggi (>15\%) (Goni et al., 1996; Birt et al., 2013). Hasil uji pati resisten cookies

Tabel 2. Kandungan gizi cookies tepung pisang termodifikasi dan tepung kacang hijau

\begin{tabular}{|c|c|c|c|c|c|c|c|}
\hline \multirow[t]{2}{*}{ Formulasi } & \multicolumn{6}{|c|}{ Kandungan Zat Gizi (\%) } & \multirow[b]{2}{*}{ Pati resisten } \\
\hline & Karbohidrat & Lemak & Protein & Abu & Air & Serat pangan & \\
\hline $85: 15$ & $45,72 \pm 0,58^{a}$ & $18,53 \pm 0,21^{a}$ & $5,62 \pm 0,07^{a}$ & $3,70 \pm 0,10^{a}$ & $11,22 \pm 0,47^{a}$ & $15,18 \pm 0,39^{a}$ & $13,67 \pm 1,97^{a}$ \\
\hline $75: 25$ & $42,07 \pm 1,35^{b}$ & $18,99 \pm 0,38^{b}$ & $7,01 \pm 0,18^{b}$ & $4,45 \pm 0,23^{b}$ & $9,83 \pm 0,23^{b}$ & $17,62 \pm 0,90^{\mathrm{b}}$ & $11,33 \pm 1,63^{a b}$ \\
\hline $65: 35$ & $40,16 \pm 0,72^{c}$ & $18,45 \pm 0,14^{a}$ & $7,83 \pm 0,39^{c}$ & $3,65 \pm 0,12^{a}$ & $12,22 \pm 0,43^{c}$ & $17,70 \pm 1,00^{\mathrm{b}}$ & $10,33 \pm 1,50^{b}$ \\
\hline Nilai $p$ & $0,001^{\star \star}$ & $0,006^{*}$ & $0,001^{\star \star}$ & $0,001^{*}$ & $0,001^{\star \star}$ & $0,001^{*}$ & $0,024^{\star \star}$ \\
\hline
\end{tabular}

Keterangan : Angka yang diikuti huruf superscript yang berbeda menujukkan beda nyata $\left({ }^{*}\right)$ artinya hasil dari analisis One way Anova; $\left({ }^{* *}\right)$ artinya hasil analisis dengan Kruskal Wallis Test

Tabel 3. Kadar glukosa darah setelah konsumsi cookies

\begin{tabular}{lcccccc}
\hline & \multicolumn{2}{c}{ Kelompok cookies $85: 15$} & \multicolumn{2}{c}{ Kelompok cookies 75:25 } & \multicolumn{2}{c}{ Kelompok cookies 65:35 } \\
\hline Waktu & Roti Tawar & Cookies & Roti Tawar & Cookies & Roti Tawar & Cookies \\
\hline Menit ke-0 & $83,90 \pm 8,03$ & $82,90 \pm 6,85$ & $78,10 \pm 7,37$ & $85,60 \pm 7,39$ & $81,60 \pm 3,71$ & $84,50 \pm 7,75$ \\
Menit ke-30 & $121 \pm 15,50$ & $102,80 \pm 10,87$ & $114,10 \pm 14,46$ & $109,50 \pm 12,76$ & $118,20 \pm 9,25$ & $107 \pm 9,93$ \\
Menit ke-60 & $122 \pm 18,35$ & $98,90 \pm 13,04$ & $117,50 \pm 15,88$ & $93,30 \pm 9,44$ & $123,50 \pm 14,43$ & $98,70 \pm 9,84$ \\
Menit ke-90 & $97,50 \pm 6,55$ & $90,80 \pm 9,75$ & $96,60 \pm 12,79$ & $85,70 \pm 8,17$ & $101,50 \pm 12,57$ & $91 \pm 8,85$ \\
Menit ke-90 & $85,50 \pm 10,62$ & $83,30 \pm 8,46$ & $86,20 \pm 12,20$ & $80 \pm 6,71$ & $86,50 \pm 9,84$ & $83,50 \pm 6,46$ \\
\hline
\end{tabular}

Tabel 4. Indeks dan beban glikemik 3 jenis formulasi cookies dengan jumlah penyajian $30 \mathrm{~g}$

\begin{tabular}{lccccc}
\hline Jenis Cookies & $\begin{array}{c}\text { Karbohidrat } \\
\text { available (\%) }\end{array}$ & $\begin{array}{c}\text { Karbohidrat } \\
\text { available/porsi }(\%)\end{array}$ & Indeks glikemik Beban glikemik & Kategori \\
\hline $85: 15$ & 45,72 & 13,72 & 49,10 & 6,74 & Rendah \\
$75: 25$ & 42,07 & 12,62 & 29,50 & 3,72 & Rendah \\
$65: 35$ & 40,16 & 12,05 & 42,34 & 5,10 & Rendah \\
\hline
\end{tabular}


tepung pisang kepok termodifikasi enzimatis dan tepung kacang hijau sesuai pada Tabel 2 menunjukkan bahwa semua formulasi cookies memiliki kadar pati resisten sangat tinggi $(>15 \%)$. Semakin tinggi presentase komposisi tepung pisang kepok termodifikasi enzimatis semakin tinggi kadar pati resisten yang terkandung pada cookies. Hasil uji statistik menunjukkan bahwa substitusi tepung pisang kepok termodifikasi enzimatis menaikkan secara nyata kadar pati resisten. Penelitian sebelumnya oleh Sajilata et al. (2006) melaporkan bahwa kadar amilosa yang tinggi dibutuhkan dalam proses pembentukan pati resisten yang dihasilkan suatu produk. Selain itu kadar pati resisten tepung pisang juga meningkat signifikan dengan pemberian perlakuan pemanasan. Hidrolisis pati resisten oleh enzim pencernaan umumnya memerlukan waktu yang lebih lambat, sehingga mengkonsumsi pati resisten yang dapat menurunkan kandungan gula darah. Hal tersebut disebabkan oleh pati resisten yang menghasilkan energi dengan proses yang cukup lambat, sehingga tidak segera diserap dalam bentuk glukosa. Selain itu, menurut Herawati (2010) keberadaan pati resisten juga meningkatkan keberadaan GLP-1 (glucagon like peptide 1), dimana GLP-1 ini menstimulasi pembentukan insulin. Pati resisten juga memiliki efek yang dapat mengurangi respon glikemik dan insulin, menurunkan kolesterol, efek protektif terhadap kanker kolon melalui proses mikroflora yang mampu mengubah pati resisten menjadi asam lemak rantai pendek (Alejandro et al., 2007). Oleh karena itu diharapkan dengan tingginya pati resisten dalam cookies, nilai indeks glikemik pangan tersebut rendah.

\section{Analisis Indeks Glikemik dan Beban Glikemik}

Respon kenaikan nilai glukosa darah tiap kelompok perlakuan menunjukkan bahwa rata-rata peningkatan respon kadar glukosa darah pangan uji (cookies) lebih rendah dibandingkan dengan pangan acuan (roti tawar) sebagaimana ditampilkan pada Tabel 3. Berdasarkan pengamatan berkala yang telah dilakukan, puncak kenaikan kadar glukosa darah terjadi pada menit ke-60 setelah makan dan menurun secara bertahap pada menit-menit selanjutnya, sedangkan perlakuan cookies, puncak kenaikan kadar glukosa darah terjadi pada menit ke-30 dengan puncak peningkatan kadar glukosa darah tertinggi terdapat pada pemberian pangan acuan roti tawar sebesar 123,50 $\mathrm{mg} / \mathrm{dl}$ dan peningkatan glukosa darah terendah pada pemberian cookies dengan formula tepung pisang dan kacang hijau $85: 15 \%$, yaitu sebesar $102,80 \mathrm{mg} / \mathrm{dl}$.

Indeks glikemik berdasarkan perhitungan luas area bawah kurva dihitung dengan metode trapezoid. Setelah dirata-ratakan, didapatkan nilai indeks glikemik makanan uji ditampilkan pada Tabel 4. Hasil perhitungan menunjukkan bahwa nilai indeks glikemik cookies termasuk dalam kategori IG rendah $(I G<55)$ yaitu 29,50 49,10 . Adanya penurunan IG dapat disebabkan oleh banyak faktor, diantaranya adalah cara pengolahan, kadar serat, protein, lemak, serta pati resisten (Arif et al., 2013). Berdasarkan Tabel 4, cookies memiliki beban glikemik yang tergolong rendah $(<10)$ dengan beban glikemik paling rendah yaitu 3,72 sampai 6,74 . Beban glikemik suatu produk makanan juga dipengaruhi oleh kadar karbohidrat available yang terdapat dalam satu takaran saji. Porsi penyajian dapat mempengaruhi besar dan kecilnya beban glikemik. Pada penelitian ini porsi penyajian cookies tepung pisang kepok dan tepung kacang hijau adalah sebesar 30 gram dengan indeks glikemik dan beban glikemiks yang rendah sehingga aman sebagai alternatif makanan selingan bagi penderita DM tipe 2.

\section{Analisis Daya Terima Cooekies}

Tabel 5 menunjukkan bahwa formulasi tepung pisang kepok termodifikasi dan tepung kacang hijau tidak ada perbedaan yang nyata terhadap daya terima warna, aroma, dan rasa tetapi terdapat perbedaan nyata terhadap daya terima tekstur cookies. Berdasarkan hasil analisa data dapat diketahui bahwa cookies dengan formula $85: 15 \%$ untuk tepung pisang dan tepung kacang hijau memiliki tingkat kesukaan terhadap warna tertinggi, namun semua formulasi masuk ke dalam kategori yang sama yaitu kategori suka. Hasil analisis berdasarkan metode de Garmo et al. (1984) menunjukkan bahwa cookies dengan formula rasio tepung pisang dan tepung kacang hijau sebesar 85 dan 15\%, merupakan formula terbaik dengan nilai hasil tertinggi sebesar 0,599 (data tidak ditampilkan) yang dapat menghasilkan cookies dengan kandungan karbohidrat $45,72 \%$, protein $5,62 \%$ , lemak $18,53 \%$, air $11,22 \%$, abu $3,70 \%$, serat pangan $15,18 \%$, pati resisten $13,67 \%$, serta skor penerimaan terhadap warna, aroma, rasa, dan tekstur masingmasing sebesar 2,92, 3,08, 2,80 dan 3,12.

Tabel 5. Hasil analisis tingkat kesukaan cookies tepung pisang termodifikasi dan tepung kacang hijau

\begin{tabular}{|c|c|c|c|}
\hline \multirow[t]{2}{*}{ Aspek } & \multicolumn{3}{|c|}{ Persentase tepung pisang dan kacang hijau } \\
\hline & $85: 15$ & $75: 25$ & $65: 35$ \\
\hline Warna & $\begin{array}{l}2,92 \pm 0,50^{a} \\
\text { (Suka) }\end{array}$ & $\begin{array}{c}3,04 \pm 0,20^{a} \\
\text { (Suka) }\end{array}$ & $\begin{array}{c}3,12 \pm 0,78 \text { a } \\
\text { (Suka) }\end{array}$ \\
\hline Aroma & $\begin{array}{c}3,08 \pm 0,57 \text { a } \\
\text { (Suka) }\end{array}$ & $\begin{array}{c}3,16 \pm 0,69 \text { a } \\
\text { (Suka) }\end{array}$ & $\begin{array}{c}3,00 \pm 0,82 \text { a } \\
\text { (Suka) }\end{array}$ \\
\hline Rasa & $\begin{array}{c}2,80 \pm 0,64 \text { a } \\
\text { (Suka) }\end{array}$ & $\begin{array}{c}2,84 \pm 0,55 \text { a } \\
\text { (Suka) }\end{array}$ & $\begin{array}{c}2,60 \pm 0,76 \text { a } \\
\text { (Suka) }\end{array}$ \\
\hline Tekstur & $\begin{array}{c}3,12 \pm 0,73^{a} \\
\text { (Suka) }\end{array}$ & $\begin{array}{c}3,12 \pm 0,73 \text { a } \\
\text { (Suka) }\end{array}$ & $\begin{array}{c}2,44 \pm 0,82^{\mathrm{b}} \\
\text { (Tidak Suka) }\end{array}$ \\
\hline
\end{tabular}

Keterangan: Angka yang diikuti huruf superscript yang berbeda $(a, b, c)$ menunjukkan beda nyata

\section{Kesimpulan}

Berdasarkan hasil penelitian yang diperoleh bahwa semakin tinggi komposisi tepung pisang kepok termodifikasi, maka semakin tinggi kadar pati resisten dan karbohidrat pada cookies. Formulasi terbaik dengan mempertimbangkan mutu cookies yang meliputi kandungan gizi, pati resisten, indeks glikemik, beban glikemik dan daya terima adalah cookies dengan dengan formula $85: 15 \%$ untuk tepung pisang dan tepung kacang hijau yang menghasilkan nilai hasil yang tertinggi.

\section{Ucapan Terima Kasih}

Terima kasih peneliti sampaikan kepada Penelitian Terapan Unggulan Perguruan Tinggi (PTUPT) sumber dana Direktorat Riset dan Pengabdian 
Masyarakat Direktorat Jenderal Penguatan Riset dan Pengembangan Kemenristek Dikti dengan Nomor Kontrak: 101-91/UN7.P4.3/PP/2018 yang telah mendanai penelitian ini.

\section{Daftar Pustaka}

Afifah, D.N., Putrianti, A.S., Tunjung, A.P.S., Rustanti, N. 2018. Effect of processing methods on glycemic index of chocolate crackers made with modified kepok banana (Mussa paradisiaca L.) flour. International Journal of Food Engineering 4(4):299-303. DOI: 10.18178/ijfe.4.4.299-303.

Alejandro, A.S., Sàyoga-Ayerdi, S.G., Vargas-Torres, A., Tovar, J., Ascencio-Otero, T.E., Bello-Pérez, L.A. 2007. Slowly digestible cookies prepared from resistant starch-rich lintnerized banana strach. Journal of Food Comporition and Analysis 20(34):175-181. DOI:10.1016/j.jfca.2006.07.005.

Andarwulan, N., Kusnandar, F., Herawati, D. 2011. Analisis Pangan. Dian Rakyat, Jakarta.

Aquino, C.F., Salamão, L.C.C., Ribeiro, S.M.R., Siqueira, D.L.D., Cecon, P.R. 2016. Carbohydrates, Phenolic Compounds and Antioxidant Activity in Pulp and Peel of 15 Banana Cultivars. Revista Brasileira de Fruticultura 38(4): 1-11. DOI: 10.1590/0100-29452016090.

Arif, A.B., Budiyanto, A., Hoerudin. 2013. Nilai indeks glikemik produk pangan dan faktor-faktor yang mempengaruhinya. Jurnal Litbang Pertanian 32(2):91-9.

Asp, N.G., Johansson, C.G., Hallmer, H., Siljestroem, M. 1983. Rapid enzymatic assay of insoluble and soluble dietary fiber. Journal of Agricultural and Food Chemistry 31(3):476-482. DOI: 10.1021/ff00117a003.

Association of Official Analytical Chemists (AOAC). 2005. Official Methods of Analysis of the Association of Analytical Chemists. AOAC, Inc, Virginia.

Atkinson, F.S., Foster-powell, K., Brand-Miller, J.C. 2008. International table of glycemic index and glycemic load values. Diabetes Care 31(12):2281-2883. DOI: 10.2337/dc08-1239.

Birt, D.F., Boylston, T., Hendrich, S., Jane, J.L., Hollis, J., Li., McClelland, J., Moore, S., Phillips, G.J., Rowling, M., Schalinske, K., Scott, M.P., Whitley, E.M. 2013. Resistant Starch: Promise for Improving Human Health. Advances in Nutrition 4(6): 587-601. DOI: 10.3945/an.113.004325.

Canivell, S., Gomis R. 2014. Diagnosis and classification of autoimmune diabetes mellitus. Autoimmunity Reviews 13(4-5):403-407.

DOI: 10.1016/j.autrev.2014.01.020.

Cho, N.H., Shaw, J.E., Karuranga, S., Huang, Y., da Rocha Fernandes, J.D., Ohlrogge, A.W., Malanda, B. 2018. IDF Diabetes atlas: Global estimates of diabetes prevalence for 2017 and projections for 2045. Diabetes Research and Clinical Practice 138:271-281. DOI: 10.1016/j.diabres.2018.02.023. de Garmo, E., Sullivan, W., Canada, J. 1984. Engineering Economy. Mc Millan Publishing Company, New York.

Diyah, N.W., Ambarwati, A., Warsito, G.M., Niken, G., Heriwiyanti, E.T., Windysari, R., Prismawan, D., Hartasari, R.F., Purwanto. 2016. Evaluasi kandungan glukosa dan indeks glikemik beberapa sumber karbohidrat dalam upaya penggalian pangan ber-indeks glkemik rendah. Jurnal Farmasi dan IImu Kefarmasian Indonesia 3(2):6772. DOI:10.20473/fiki.v3i22016.67-73.

Franz, M.J. 2012. Medical nutrition theraphy for diabetes mellitus and hypoglycemia of nondiabetic. In: Mahan LK, SE S, editors. Krause's Food and the Nutrition Care Process. WB Saunders Company, Philadelphia.

Gallagher, M.L. 2012. The Nutrient and Their Metabolism. In: In: Mahan LK, Stump SE, editor. Krause's Food and the Nutrition Care Process $13^{\text {th }}$ edition. WB Saunders Company, Philadelphia.

Granfeldt, Y., Wu, X., Björck, I. 2006. Determination of glycemic index; some methodological aspects related to the analysis of carbohydrate load and characteristics of the previous evening meal. European Journal of Clinical Nutrition 60(1):104112. DOI:10.1038/sj.ejcn.1602273.

Herawati, H. 2010. Potensi pengembangan produk pati tahan cerna sebagai pangan fungsional. Balai Pengkajian Teknologi Pertanian. Jakarta.

Istiqomah, A., Rustanti, N. 2015. Indeks glikemik, beban glikemik, kadar protein, serat, dan tingkat kesukaan kue kering tepung garut dengan substitusi tepung kacang merah. Journal Nutrition College 4(2):620-7. DOI:10.14710/jnc.v4i4.10171.

Kementerian Kesehatan Republik Indonesia (Kemenkes). 2018. Hasil utama Riskesdas 2018. Badan Penelitian dan Pengembangan Kesehatan Kementerian Kesehatan Republik Indonesia, Jakarta.

Kim, S-K., Kwak, J-E., Kim, W-K. 2003. A simple method for estimation of enzyme-resistant starch content. Starch 55(8):366-368. DOI: 10.1002/star.200300199.

Musita, N. 2012. Kajian kandungan dan karakteristiknya pati resisten dari berbagai varietas pisang. Jurnal Dinamika Penelitian Industri 23(1):57-65. DOI: 10.28959/jdpi.v23i1.557.

Mustakim, M. 2013. Budidaya Kacang Hijau Secara Intensif. Pustaka Baru Press, Yogyakarta.

Nurhayati, Jenie, B.S.L., Widowati, S., Kusumaningrum, H.D. 2014. Komposisi kimia dan kristalinitas tepung pisang termodifikasi secara fermentasi spontan dan siklus pemanasan bertekananpendingin. Agritech 34(2): 146-150. DOI: 10.22146/agritech.9504.

Olwin, N., Cornelis, A. 2005. Diet Sehat Dengan Serat. Cermin Dunia Kedokteran No. 147. Departemen Kesehatan RI, Jakarta.

Purwono., Hartono, R. 2005. Kacang hijau. Penebar Swadaya, Jakarta. 
Robertson, M.D. 2012. Dietary-resistant starch and glucose metabolism. Current Opinion in Clinical Nutrition and Metabolic Care 15(4): 362-367. DOI: 10.1097/MCO.0b013e3283536931.

Setiarto, R.H.B., Jenie, B.S.L., Faridah, D.N., Saskiawan, I. 2015. Kajian peningkatan pati resisten yang terkandung dalam bahan pangan sebagai sumber prebiotik. Jurnal IImu Pertanian Indonesia (JIPI) 20(3):191-200. DOI: 10.18343/jipi.20.3.191.

Siagan, R.A. 2004. Faktor-faktor yang mempengaruhi indeks glikemik pangan, indeks glikemik dan beban glikemik beberapa jenis pangan indeks glikemik pangan: Cara mudah memilih pangan yang menyehatkan. Penebar Swadaya, Jakarta.

Sudarmadji, S., Haryono, B., Suhardi. 1997. Analisa Bahan Makanan dan Pertanian. Penerbit Liberty, Yogyakarta.
Venn, B.J., Wallace, A.J., Monro, J.A., Perry, T., Brown, R., Frampton, C., Green, T.J. 2006. The glycemic load estimated from the glycemic index does not differ greatly from that measured using a standard curve in healthy volunteers. The Journal of Nutrition 136(5): 1377-81. DOI: 10.1093/jn/136.5.1377.

Wild, S., Roglic, G., Green, A., Sicree, R., King, H. 2004. Global prevalence of diabetes: estimates for the year 2000 and projections for 2030. Diabetes Care 27(5): 1047-53. DOI: 10.2337/diacare.27.5.1047

Zhang, W.Q., Wang, H.W., Zhang, Y.M., Yang, Y.X. 2007. Effect of Resistant Starch on Insulin Resistance of Type 2 Diabetes Mellitus Patients. Chinese Journal of Preventive Medicine 41(2): 101-104. PMID: 17605234. 